TrisnaHelda $^{1}$; Sri Imelwaty ${ }^{2}$; Wahyudi Rahmat ${ }^{3}$

\title{
Factors Affecting the Pre-service Student Teachers' Performance in Implementing the Questioning Skills in their Microteaching Practices
}

\begin{abstract}
Questioning is one of the skills which should be practiced by the pre-service student teachers before they undergo the real teaching practices at schools. To this end, the study aims are to explore the factors which affecting the pre-service student teachers' performance in implementing the questioning skills during their microteaching practices. This study employed a case study research design by collecting qualitative data. A small group consisting of 32 pre-service student teachers was interviewed regarding what things affecting their performance in implementing the questioning skills when teaching Bahasa Indonesia, the official language of Indonesia, during their microteaching practices. Thematic analysis was conducted for analyzing the qualitative data. The findings show the internal and external factors affecting their performance in implementing the questioning skills during their microteaching practices. The study findings could inform the improvement of the microteaching practices to increase the pre-service student teachers' performances.
\end{abstract}

Keywords: Pre-service student teachers, questioning skills, microteaching

doi:

Makalah diterima redaksi: 27, 02, 2020

Makalah disetujui untuk dipublikasikan: 16, 03, 2020

\footnotetext{
*PPJB-SIP: Perkumpulan Pengelola Jurnal Bahasa dan Sastra Indonesia serta Pengajarannya

${ }^{1}$ TrisnaHelda: trisna@stkip-pgri-sumbar.ac.id; STKIP PGRI Sumatera Barat

${ }^{2}$ Sri Imelwaty: imelwaty05@stkip-pgri-sumbar.ac.id; STKIP PGRI Sumatera Barat

${ }^{3}$ Wahyudi Rahmat: wahyudirahmat24@gmail.com; STKIP PGRI Sumatera Barat
} 


\section{Introduction}

Microteaching is one of the courses at teacher colleges that have an aim to train the preservice student teachers applying the small (micro) teaching and learning theories for a simulation of the learning process, in which the students act as teachers and other pre-service students as students. Microteaching introduces several teaching skills that the pre-service student teachers exercise during their course in the sixth semester. This course is a compulsory one that must be taken by the students of the Indonesian Language and Literature Education Study Program at a teacher college in Indonesia. The expected abilities to be acquired by the pre-service student teachers consist of 1) opening and closing the class skills, 2) explaining skills, 3) questioning skills (Zhang\& Patrick, 2012), 4) strengthening skills, 5) learning media learning skills, 6) discussion for guiding skills in small groups, 7) classroom management skills, 8) variation skills and 9) individual and small group teaching skills (Suwarna et al., 2006).

The microteaching practices in the Indonesian Language and Literature Education Study Programs are also focusing the programs on debriefing the various skills that the students must have to become a teacher. These pre-service student teachers are trained to teach in an independent manner which cannot be separated from the lecturers' guidance in the microteaching practices. The participants of the course are exposed to the curriculum at the Indonesian Language and Literature Education Study Program which has been adjusted to the educational guidelines, namely the 2013 curriculum. The lecturers of the microteaching course also provide an understanding of the teaching skills and the preparation of learning; so that the given materials could equip the students to achieve the course learning outcomes. After completing this course, the students are expected to be ready to teach Bahasa Indonesia, the official language of the Republic of Indonesia, for the middle and high school students. To this end, the lecturers must be able to master the knowledge of teaching and be able to provide effective examples so that the prospective teachers could obtain better competence and performance.

One of the skills that become the focus of teaching which is very influential for enhancing the student abilities in teaching and learning activity is the questioning skill (Etemadzadeha, Seifi, \&Farc, 2013; Supriusman, 2015). The questioning skill is a way of conveying a lesson through twoway interactions, from the teacher to the students and from the students to the teachers, so that the teachers could know whether their students are following them or not (Taufik, Rivaie, \&Sulistyarini, 2013;Astuti, 2015).Asking or providing questions is one of the main functions of a language besides other functions, such as expressing opinions, feelings, proposing reasons to reinforce opinions (Royani\& Muslim, 2014; Rurisfiani,Ramly, \& Sultan, 2019). In line with that, Rusman, 2011;Zulkifli, \&Hashim, 2019) describes the basic principles of questioning skills that must be considered by the teacher, among others are; 1) giving questions warmly and enthusiastically to students in the class, 2) giving time for the students to think the answers of the questions, 3) Providing opportunities for those who are willing to answer first, 4) the distribution of questions, 5) transfer of turn, 6) giving time to think and 7) giving guidance.

Based on the preliminary observations which were conducted by observing the existing phenomena about the abilities of the pre-service student teachers' questioning skills in their microteaching practices, it was found a phenomenon that a number of students performed well but others failed particularly in implementing the questioning skills in their microteaching practices. The identified problems were; 1) not all of the student teachers have good teaching skills, 2) their 
performance for teaching was still low, 3)they could not implement the principles of the questioning skills, 4) not all of the students show the seriousness in conducting micro teaching practices. Based on these problems, the researchers limit the study to the questioning skills of the pre-service student teachers in their microteaching practices.

The purpose of this study isto explore the factors which affecting the pre-service student teachers' performance in implementing the questioning skills during their microteaching practices. The findings of this study could inform the improvement of microteaching practices to increase preservice student teachers' performances. In addition, it may provide information for the lecturers to evaluate their programs for preparing prospective teachers.

\section{Methods}

This study employed a case study research design by collecting the qualitative data which were obtained through interviews. According to Yin\& Moore (1987), it is "as an empirical inquiry that investigates a contemporary phenomenon within its real-life context; when the boundaries between phenomenon and context are not clearly evident; and in which multiple sources of evidence are used." This kind of research design could help researchers exploring and understanding issues in a particular context. Therefore, this design was considered appropriate with the aim and the context of the study.

The participants of this study were 32 pre-service student teachers who had undertaken the microteaching course for a semester. Both higher and lower achievers students were interviewed in reference to the questions about what things affecting their performance in implementing the questioning skills in the microteaching practices. The interviews were recorded and transcribed. The qualitative data were then ready to be analyzed.

For analyzing the data, thematic analysis was employed as the process of identifying patterns or themes within qualitative data. According to Joffe\& Yardley (2004), thematic analysis is similar to content analysis but pays greater attention to the qualitative aspects of the material analyzed. The interview transcripts were read and re-read to define the coding frame. The researcher then developed the codes and looked up for the patterns to answer the research questions.

\section{Discussion}

Based on the analysis of the qualitative data, it was revealed that there are factors affecting the pre-service student teachers' performance in implementing the questioning skills in their microteaching practices. The factors were categorized into two i.e. the internal and the external factors. The internal factors are 1) students' interest in the teaching profession, 2) students' selfconcept, 3) students' self-management. The external factors are 1) family and friends in their living environments, 2) the lecturers' abilities in guiding them, and 3) students' parental supports in teacher education programs.

Each of the internal factors is described as follow:

\section{Students Interest in the teaching profession}

It was found that out of the 32 students, there were 18 students who claimed that they were highly interested to become teachers. These were in accordance with their achievements in the microteaching course as they had performed well in their teaching practices. This interest was reflected in their statements during the interviews as stated below: 
"I like to work as a teacher because a teacher always learns and my knowledge increases a lot, so I can share it with the students who I teach".

The data also showed that the students perceived that becoming a teacher is their dream job.This idea was reflected in one of the student's statements explaining the job that he would do after graduating from college. The job is to become a teacher at either junior high or high school levels because he thought that if students have holidays and teachers also have ones as well as stated in the following statement:

"My dream job is to become a middle school or a high school teacher", this work is more flexible and it has a lot of days off".

Some advantages of this profession are seen by these many pre-service student teachers, despite the fact that this kind of job has large tasks. In the Indonesian context, the certified teachers are rewarded with a high salary by the government, so that it is common for the pre-service student teachers to expect to have the promising salaries. Besides that, the perception toward teaching is positive as it is considered an easier kind of job than others. According to these students, the teaching profession is more flexible, in terms of the working hours that are adjusted to the hours of the students, and their holidays. The teacher's risk of making a mistake is also not related to someone's life, as well as the punishments when comparing them to the work mistakes in other fields such as being scolded by the boss. Therefore, based on the obtained data, it could be inferred that the students who performed well in implementing the questioning skills were affected by their interest and expectation to be a certified teacher with a high salary to fulfill their daily needs.

\section{Student's Self Concept}

Self-concept is the student's own views toward the capabilities that they have. The students who performed well in the microteaching course held a view on the abilities that they have. They had an awareness of their own knowledge and abilities. These affected their enthusiasm when doing the tasks which were assigned to them in this course. The students were studious, serious, persistent and smart so that they were being acknowledged by other students. This was revealed when the other students were asked to give opinions about why student $\mathrm{A}$ or $\mathrm{C}$ was able to perform well in their microteaching practices. Their answers indicated that the success was due to their persistence and their willingness to learn and practice. As these students were implementing the questioning skills in the microteaching practices, they were successfully performing them. It can be inferred that their self-concept made them giving their best efforts in doing the given tasks.

\section{Self-Management}

This self-management is the ability of the students to manage various needs or activities that they are into them. Some of the business affairs or activities that are attached to them are the parttime job, the activities in variousstudent organizations on campus and other activities which are organized by students. The pre-service student teachers who take part in various businesses and activities were also assigned assignments in the microteaching practices. Their successful learning outcomes in this course depend on their capabilities in managing their activities and time. The 
students who were able to manage their time well would be able to perform well and those who could not manage their non-academic activities and time could not perform well particularly in exercising the questioning skills. This reality was revealed as the students who had poor performance admit their weaknesses during the interview as depicted below:

"I didn't practice at home to perform the microteaching practices, because I was busy preparing the event that will be held by HIMA [Students organization]".

"I love the microteaching course, but I didn't have enough time to practice my performance for microteaching practices.

From the above statements, it was known that lack of time for doing rehearsals of the microteaching practices had affected the students' performance let alone their abilities in implementing the questioning skills.

The external factors that affecting the abilities of the pre-service student teachers' performance in the microteaching practicesare:

\section{Family and Friends in their Living Environment}

Family is the closest person who often communicates with the student about their courses and assignments including microteaching courses. Some students who had good questioning skills were interviewed and it was revealed that one of his or her family members was also a teacher. As these people live close to them so that these pre-service student teachers were able to exchange ideas for understanding and implementing the microteaching tasks with their close family members. These close family members or even their parents were also able to provide opportunities that allowed these pre-service student teachers to ask about their microteaching practices. Communication with the family and the closest people at home had helped to stimulate them to enhance their abilities in implementing the questioning skills as those close people provided advice, gave solutions or even solve their problems and confusion regarding teaching and their assignments in general.

Friends who went to teacher college programs and they lived close with these pre-service students at their boarding house or in the neighborhood next to the boarding house also had parts in affecting the students' questioning skills in their microteaching practices. The successful students admitted that if they had friends who were also in the teacher education program, they would have opportunities to exchange ideas or to seek advice. They could learn together, respond to each other problems, correct and give inputs. As a result of this condition, the pre-service student teachers had the confidence to implement the teaching skills in their microteaching practices. These findings indicate that the treatment from family and friends in their living environment was influential on the students' performance particularly in implementing the questioning skills in the microteaching practices.

\section{The Lecturers abilities in guiding them}

Based on the interview results, it was found that the communication with the lecturers in their microteaching course also influenced these pre-service student teachers' successes in 
conducting the microteaching practices. The teaching skills such as the questioning skills were never been learned by the students in the previous courses. Other courses before were curriculum planning, Indonesian teaching and evaluating and Indonesian language teaching. The wellperformance students admitted thatthe clarity of the given information and knowledge which were delivered by their lecturers would influence their mastery of the theories. The knowledge of knowwhat and know-how would definitely help the pre-service student teachers to do the microteaching practices. In other words, the lecturers' abilities to provide procedural knowledge, the clear technical procedure of teaching, clear instructions or even the motivation would affect their students' performances. Besides, the lecturers' supports and guidance took an important role in their students' professional growth. One of the abilities of the lecturers in teaching was on how the lecturers provide reward and punishment about the performed task.The reward is given to the students who have tried to present their best practices, as well as to follow-up the underachiever students to make up their performance in the next tasks.

\section{Students' Parental Supports in Teacher Education Programs}

From interviewing the pre-service student teachers who performed well in their microteaching practices, it was revealed that their parental supports played important roles in their success. The supports were in the form of funding, providing the facilities in doing coursework. In addition, these students claimed that their parents had built a good communication with them so that both students and the parents were able to discuss what they were doing in their study program. This kind of psychological support was essential to develop the students' self-esteem and their confidence in conducting the given assignments. According to these students, their parents continuously checked and monitored their progress in their teacher education program so that they felt being supported by their parents.

\section{Conclusion}

The questioning skills are one of the important skills in teaching which should be mastered by the pre-service student teachers. During the microteaching practices, it was identified that a number of student success but some other failed particularly implementing the questioning skills. This study has made an attempt to reveal what factors affecting the students. The interview results showed that there were internal and external factors affecting the students' performance. The internal factors comprise the students' interest, self-concept, and self-management. These factors should be developed and introduce to the students so that their inner motivation could develop well. While the external factors comprise the family, friends, and parents support is also needed to boost the students' motivation in achieving their educational goals. The results of this study could inform the lecturers of the microteaching course and the policymakers in the teacher education program to develop the programs for the pre-service student teachers in achieving their learning outcomes.

\section{References}

Astuti, M. S. (2015). Peningkatan Keterampilan Bertanya dan Hasil Belajar Siswa Kelas 2 SDN Slungkep 03 Menggunakan Model Discovery Learning. Scholaria: Jurnal Pendidikan dan Kebudayaan, 5(1), 10 - 23. 
Etemadzadeha, A., Seifi, S., \&Farc, H. R. (2013). The role of questioning technique in developing thinking skills: The ongoing effect on writing skill. Procedia - Social and Behavioral Sciences, 70(2013), $1024-1031$.

Joffe, H., \& Yardley, L. (2004). Content and thematic analysis: Research methods for clinical and health psychology. London: Sage.

Rurisfiani, A.,Ramly, \& Sultan. (2019). Level Berpikir Pertanyaan Guru pada Pembelajaran Bahasa Indonesia. Bahasa: Jurnal Keilmuan Pendidikan Bahasa dan Sastra Indonesia, 1(2), 111 119.

Rusman. (2011). Model-Model Pembelajaran. Jakarta: PT Raja GrafindoPersada.

Royani, M., \& Muslim, B. (2014).Keterampilan Bertanya Siswa SMP Melalui Strategi Pembelajaran Aktif Tipe Team Quiz Pada Materi Segi Empat. EDU-MAT: Jurnal Pendidikan Matematika, 2(1), $22-28$.

Supriusman. (2015). Questions and Questioning Skills In ELT. The Journal of English Literacy Education, 2(2), 58 - 68.

Suwarna, dkk. (2006). Pengajaran Mikro Pendekatan Praktis dalam Menyiapkan Pendidik Profesional. Yogyakarta: Tiara Wacana.

Taufik, R., Rivaie, W., \&Sulistyarini. (2013). Kemampuan Guru Menerapkan Keterampilan Bertanya Pada Pelajaran Sosiologi di Kelas XI SMA Islamiyah Pontianak. Jurnal Pendidikan dan Pembelajaran Khatulistiwa, 2(4), 1 - 12.

Yin, R. K., \& Moore, G. B. (1987). The use of advanced technologies in special education: Prospects from robotics, artificial intelligence, and computer simulation.Journal of Learning Disabilities, 20(1), 60-63.

Zhang, Y., \& Patrick, P. (2012). Introducing Questioning Techniques to Pre-service Teachers. Journal of Teacher Education and Educators, 1(2), 159 - 184.

Zulkifli, H., \&Hashim, R. (2019). The Development of Questioning Skills through Hikmah (Wisdom) Pedagogy. Creative Education, 10, 2593 - 2605. 